\title{
PORTAL VEIN THROMBOSIS IN CHILDREN AND ADOLESCENTS: 20 years experience of a pediatric hepatology reference center
}

\author{
Priscila Menezes FERRI ${ }^{1}$, Alexandre Rodrigues FERREIRA², Eleonora Druve Tavares FAGUNDES ${ }^{3}$, \\ Shinfay Maximilian LIU ${ }^{4}$, Mariza Leitão Valadares ROQUETE ${ }^{5}$ and Francisco José PENNA ${ }^{6}$
}

\begin{abstract}
Context - Portal vein thrombosis refers to a total or partial obstruction of the blood flow in this vein due to a thrombus formation. It is an important cause of portal hypertension in the pediatric age group with high morbidity rates due to its main complication - the upper gastrointestinal bleeding. Objective - To describe a group of patients with portal vein thrombosis without associated hepatic disease of the Pediatric Hepatology Clinic of the Hospital das Clínicas, Universidade Federal de Minas Gerais, Belo Horizonte, MG, Brazil with emphasis on diagnosis, presentation form and clinical complications, and the treatment of portal hypertension. Methods - This is a descriptive study of a series of children and adolescents cases assisted from January 1990 to December 2010. The portal vein thrombosis diagnosis was established by ultrasound. Results - Of the 55 studied patients, $30(54.5 \%)$ were male. In 29 patients $(52.7 \%)$, none of the risk factors for portal vein thrombosis was observed. The predominant form of presentation was the upper gastrointestinal bleeding (52.7\%). In 20 patients (36.4\%), the initial manifestation was splenomegaly. During the whole following period of the study, 39 patients $(70.9 \%)$ showed at least one episode of upper gastrointestinal bleeding. The mean age of patients in the first episode was $4.6 \pm 3.4$ years old. The endoscopic procedure carried out in the urgency or electively for search of esophageal varices showed its presence in $84.9 \%$ of the evaluated patients. The prophylactic endoscopic treatment was performed with endoscopic band ligation of varices in $31.3 \%$ of patients. Only one died due to refractory bleeding. Conclusions - The portal vein thrombosis is one of the most important causes of upper gastrointestinal bleeding in children. In all non febrile children with splenomegaly and/or hematemesis and without hepatomegaly and with normal hepatic function tests, it should be suspect of portal vein thrombosis. Thus, an appropriate diagnostic and treatment approach is desirable in an attempt to reduce morbidity and mortality.
\end{abstract}

HEADINGS - Venous thrombosis. Portal vein. Hypertension, portal. Child. Adolescent.

\section{INTRODUCTION}

Portal vein thrombosis (PVT) refers to a total or partial obstruction of the blood flow in this location, secondary to a thrombus formation. These thrombus may extend until the liver, affecting intra-hepatic vases, or reach splenic and/or mesenteric veins ${ }^{(6,34)}$. The first PVT case was described in 1868 by Balfour and Stewart ${ }^{(5)}$, in a patient with splenomegaly, ascites and esophageal varices. Recently, the number of diagnoses is increasing, possibly due to the greater availability of diagnostic methods, specially the Doppler ultrasound ${ }^{(6,25,47,50)}$. PVT incidence in the general population is estimated in $1 \%$ after the study carried out by Ogren et al. ${ }^{(31)}$ in autopsies.

In adults, factors that lead to hypercoagulability are the main cause of PVT not associated with liver cirrhosis or cancer ${ }^{(34)}$. Among the local risk factors, situations that increase the intra-abdominal inflammatory response as acute or chronic pancreatitis, diverticulitis, appendicitis, inflammatory bowel diseases, liver abscesses, cholangitis and surgeries have been described ${ }^{(12,15,31,33,34)}$. In children and adolescents, the main identified causes are: direct injury of the vein (omphalitis and umbilical vein catheterization) and sepsis with abdominal focus ${ }^{(29,41,50)}$. Others possible causes are abdominal trauma, surgical trauma, cysts and tumors in the porta hepatis, neonatal sepsis, dehydration, cardiovascular malformations and exchange transfusion ${ }^{(6,41,50,52)}$. Most of the cases remain idiopathic ${ }^{(32,35,40)}$.

PVT is important in the pediatric age group because it is one of the most frequent causes of portal hypertension, with high morbidity rates due to its main complication - the upper gastrointestinal bleeding. Approximately $79 \%$ of the children diagnosed with PVT will show at least one episode of upper gastrointestinal bleeding during their lives ${ }^{(2,41)}$. In

The authors have no conflicts of interests to declare.

Departamento de Gastroenterologia Pediátrica do Hospital das Clínicas da Universidade Federal de Minas Gerais (UFMG), Belo Horizonte, MG, Brasil.

Correspondence: MD Priscila Menezes Ferri - Rua São Romão, 197/202 - 30.330.120 - Santo Antônio, Belo Horizonte, MG, Brazil. E-mail: pmferri.liu@gmail.com 
the literature there are few reports on PVT in children and adolescents, being some of them also studies about casuistic descriptions and others about specific characteristics of the disease as thrombophilia ${ }^{(1,17,20,32,43,45,48,53,54,55)}$.

Due to the scarcity of studies in the pediatric age group and the importance of the theme, this study's objective is to describe the clinical characteristics, diagnosis, evolution and treatment of the portal hypertension in children and adolescents with diagnosis of portal vein thrombosis assisted at the Pediatric Hepatology Clinic of the Hospital das Clínicas of Universidade Federal de Minas Gerais (UFMG), Belo Horizonte, MG, Brazil.

\section{METHODS}

\section{Patients}

This is a descriptive study of a series of children and adolescents cases that were diagnosed with PVT and were assisted at the Pediatric Hepatology Clinic of the Hospital das Clínicas of UFMG from January 1990 to December 2010. The PVT diagnosis was established by ultrasound where cavernomatous transformation of the portal vein was observed. The exclusion of associated hepatic disease was carried out through clinical, laboratorial and radiological evaluation.

The following variables were evaluated: gender, age at the diagnosis, birth conditions (weight and complications in the perinatal period, such as infections, use of umbilical catheter and omphalitis history), form of disease presentation, alterations at the physical exam, disease complications, laboratory tests and approach of the secondary prophylaxis of the upper gastrointestinal bleeding due to esophagogastric varices.

When hepatomegaly was observed on clinical examination, patients were tested for the presence of chronic liver disease that could be the cause of this finding. The evaluation included viral hepatitis, autoimmune hepatitis, alpha-1-antitrypsin deficiency, Wilson's disease among others, through laboratory tests. If these diseases were discarded and the patient had liver enzymes (AST, ALT, GGT, ALP) and bilirubin within the reference values, liver biopsy was not performed.

Until the time of completion of this series, the full assessment of the hypercoagulability tests was not available in the laboratory service of Hospital das Clínicas. Thus, it was not part of the purpose of this study to evaluate hypercoagulability due to incomplete data.

\section{Endoscopic treatment}

All patients with upper gastrointestinal bleeding, after the emergency approach, were elective referred to perform a secondary endoscopic prophylaxis - sclerotherapy or endoscopic band ligation (EBL).

Endoscopic treatment was carried out in the Endoscopy Unit of the Alfa Institute of Gastroenterology of the Hospital das Clínicas (UFMG), always in a same week day, by two pediatric endoscopists who were simultaneously present during the exam. Varices were classified according to the Japanese classification (Japanese Research Society for Portal Hypertension, 1980), using as parameters the varices' diameter and shape. They were classified in three grades: grade I (small caliber) - small, nontortuous varices; grade II (medium caliber) — slightly wide and tortuous varices, occupying less than one third of the esophageal lumen; grade III (large caliber) — nodular varices, similar to rosary beads, occupying more than one third of the esophageal lumen.

Gastric varices were classified as esophagogastric varices with extension along the lesser curvature of the stomach (GEV1S type); esophagogastric varices extending along the greater curvature towards the gastric fundus (GEV2S type); isolated varices in the gastric fundus (IGV1S); or varices located in the gastric antrum, corpus or pylorus (IGV2S).

The gastropathy classification of the portal hypertension was mild, when a mosaic pattern of light degree without presence of red spots was observed; severe, when the mosaic pattern was superimposed with red spots, or if some other red spot was present; or gastric antral vascular ectasia which is an endoscopic and histopathological entity characterized by clusters of red spots arranged in a linear pattern or diffuse lesions. The latter may be observed in others conditions than in the portal hypertension.

Sclerotherapy was carried out in children younger than 2 years old or in those who technically was not possible the passage of the apparel with the band ligation kit, with a transparent teflon ${ }^{\circledR}$ injector (diameter 23) Wilson-cook trademark, using the technique of free hand. The injection was performed intra and para vasal and the sclerosing agent used was ethamolin 3\%. The amount injected ranged from 1.0 $\mathrm{mL}$ to $1.5 \mathrm{~mL}$ per varix, according to the size of it and with a total maximum volume of $10 \mathrm{~mL}$. An injection was given in each varix, starting just above the gastroesophageal junction and, then proximally with intervals of $2 \mathrm{~cm}$ of distance. All found varices underwent sclerotherapy.

EBL was carried out through the multiband ligator. It started near to the gastroesophageal junction and ascended cranially with a distance of $5 \mathrm{~cm}$. In each session, each varix was tied using an elastic band and all found varices were treated. This technique was not used in children younger than 2 years due to technical reason. In patients who were no longer technically possible the accomplishment of the EBL, the sclerotherapy was performed for variceal eradication.

Patients underwent endoscopy every 3 weeks until the variceal eradication. After the eradication, endoscopy was carried out with a 3 months interval during the first 6 months, later a halfyearly interval and, if no varices reappeared, annual controls or, at any moment, if bleeding.

\section{Ethical issues}

The project was approved by the Ethical in Research Committee of Universidade Federal de Minas Gerais, Belo Horizonte, MG, Brazil, in April 2009 (Committee on Ethics and Research ETIC protocol 079/09). Parents or responsible and the children/ adolescents were informed of the importance of the research, its objectives, safety on the tests' conduction and warranty of secret of data, through the informed consent term.

\section{Statistical analysis}

Data were analyzed through the software Excel $2007^{\circledR}$ (Microsoft) and SPSS $15^{\circledR}$ (SPSS Inc.) and were evaluated through the calculation of simple frequency. The continuous variables 
without normal distribution are showed through medians and interquartiles range $25 \%-75 \%$ (IR 25\%-75\%).

\section{RESULTS}

Fifty-five children with diagnosis of PVT, without associated liver disease were evaluated, 30 patients were male $(54.5 \%)$ and 25 female $(45.5 \%)$. The age at diagnosis ranged from 1 month to 13.8 years old, with a mean age of 3.7 years, median of 2.6 years (IR 1-5.5) and standard deviation of 3.5 years. The time of the patients' follow-up had a mean of 5.5 years, a standard deviation of 4.5 years, median of 5.2 (IR 1.8-7.9) and ranged from 1 month to 19.9 years.

\section{Initial clinical manifestation}

The main initial clinical manifestations are showed in Table 1 .

TABLE 1. Initial clinical manifestation observed in 55 patients

\begin{tabular}{lc}
\hline Clinical manifestation & $\begin{array}{c}\text { Number of patients and } \\
\text { percentage }\end{array}$ \\
\hline Upper gastrointestinal bleeding & $29(52.7 \%)$ \\
Splenomegaly & $20(36.4 \%)$ \\
Occasional finding & $6(10.9 \%)$ \\
\hline
\end{tabular}

In the cases of occasional finding, one patient was under investigation due to recurrent epistaxis, three under investigation of chronic abdominal pain, one was evaluated due to the prolonged prothrombin time in a routine exam, and one was under investigation of acute abdominal pain.

\section{Risk factors}

The main risk factors observed are showed in Table 2.

Association between more than one factor was observed in 10 patients $(18.2 \%)$. The associations were between umbilical catheterization and neonatal sepsis in seven patients $(12.7 \%)$, umbilical catheterization, neonatal sepsis and hepatic abscess in one patient $(1.8 \%)$ and abdominal surgery due to enterocolitis condition, with neonatal sepsis and umbilical catheterization in another two patients $(3.6 \%)$.

TABLE 2. Risk factors involved in the PVT etiology

\begin{tabular}{lc}
\hline Risk factor & $\mathbf{n}(\%)$ \\
\hline Umbilical catheterization & $20(36.4 \%)$ \\
Neonatal sepsis & $9(16.4 \%)$ \\
Abdominal infection & $2(3.6 \%)$ \\
Cardiovascular malformation & $3(5.5 \%)$ \\
Coagulation disorder & $1(1.8 \%)$ \\
Abdominal surgery & $1(1.8 \%)$ \\
Unknown & $1(1.8 \%)$ \\
Absent & $28(50.9 \%)$ \\
\hline
\end{tabular}

In 18 patients the indication of umbilical catheterization was due to prematurity and in two patients it occurred due to other complications of the neonatal period.

Isolated abdominal infection was reported in one patient whose diagnosis was acalculous cholecystitis. Coagulation disorder was reported in one patient (antithrombin III and protein $\mathrm{S}$ deficiencies), and it was confirmed by family study. This patient was referred from another institution already diagnosed with antithrombin III and protein S deficiencies to monitor the context of portal vein thrombosis, mainly because of recurrent episodes of upper gastrointestinal bleeding. One patient, with previous diagnosis of Blackfan-Diamond syndrome, showed during the follow-up thrombosis of superior mesenteric and splenic veins and required anticoagulation. Another patient did not have a record of previous history, because the adoptive family did not have such information.

\section{Findings in the clinical and laboratorial exams}

During the physical exam carried out at the first consultation it was observed splenomegaly in 49 patients $(89.1 \%)$. Hepatomegaly was associated with splenomegaly in eight cases $(14.6 \%)$. None of the patients with hepatomegaly showed alterations in the assessment of liver function or liver enzymes and bilirubin levels were also normal. Chronic liver disease was not observed in any of these patients.

Visible collateral circulation in the abdomen was present in six patients (10.9\%), all with concomitant splenomegaly. Ascites was an isolated finding in just one patient (1.8\%). Five patients $(9.1 \%)$ did not show alterations in the clinical exam. Out of these, however, two were splenectomized. The splenectomy was performed in other services, before the PVT diagnosis, due to the massive splenomegaly and severe hypersplenism.

In the laboratorial evaluation, nine patients $(16.4 \%)$ showed elevation of hepatic enzymes (aspartate aminotransferase and/ or alanine aminotransferase) at some moment of the followup. These patients' results were on average 1.6 times above the reference value of AST and 1.7 times of ALT. Hemoglobin, International Normalized Ratio (INR ), platelet count, albumin and gamma-glutamyltransferase (GGT) in the patients' first and last consultation were also evaluated according to Table 3.

TABLE 3. Results of the laboratorial evaluation

\begin{tabular}{|c|c|c|c|c|}
\hline Evaluated item & Mean & Median & $\begin{array}{l}\text { Standard } \\
\text { deviation }\end{array}$ & $\begin{array}{l}\text { Amplitude } \\
\text { (IR) }\end{array}$ \\
\hline $\begin{array}{l}\text { Albumin }(\mathrm{g} / \mathrm{dL}) \\
1 \text { st consultation }\end{array}$ & 4.1 & 4.0 & 0.63 & $\begin{array}{c}2.6-5.1 \\
(3.8-4.4)\end{array}$ \\
\hline $\begin{array}{l}\text { Albumin }(\mathrm{g} / \mathrm{dL}) \\
\text { Last consultation }\end{array}$ & 4.1 & 4.1 & 0.54 & $\begin{array}{l}2.6-5.6 \\
(3.7-4.3)\end{array}$ \\
\hline $\begin{array}{l}\text { GGT } \\
1 \text { st consultation }\end{array}$ & 21.5 & 17.5 & 15.61 & $\begin{array}{c}2-97 \\
(14-17.5)\end{array}$ \\
\hline $\begin{array}{l}\text { GGT } \\
\text { Last consultation }\end{array}$ & 28.4 & 22.5 & 23.20 & $\begin{array}{c}1-131 \\
(28-22.5)\end{array}$ \\
\hline $\begin{array}{l}\text { Hemoglobin }(\mathrm{g} / \mathrm{dL}) \\
1 \text { st consultation }\end{array}$ & 10.5 & 10.7 & 2.40 & $\begin{array}{l}3,6-14.1 \\
(8.3-12.5)\end{array}$ \\
\hline $\begin{array}{l}\text { Hemoglobin }(\mathrm{g} / \mathrm{dL}) \\
\text { Last consultation }\end{array}$ & 11.8 & 11.9 & 2.08 & $\begin{array}{c}5.1-15.5 \\
(10.6-13.1)\end{array}$ \\
\hline $\begin{array}{l}\text { Platelets }\left(/ \mathrm{mm}^{3}\right) \\
1 \text { st consultation }\end{array}$ & 150660 & 135000 & 84164.2 & $\begin{array}{c}37000-380000 \\
(68000-200000)\end{array}$ \\
\hline $\begin{array}{l}\text { Platelets }\left(/ \mathrm{mm}^{3}\right) \\
\text { Last consultation }\end{array}$ & 117344 & 92500 & 71047.9 & $\begin{array}{c}39000-312000 \\
(68000-180000)\end{array}$ \\
\hline $\begin{array}{l}\text { INR } \\
1 \text { st consultation }\end{array}$ & 1.25 & 1.21 & 0.27 & $\begin{array}{c}0.56-2.30 \\
(1.00-1.40)\end{array}$ \\
\hline $\begin{array}{l}\text { INR } \\
\text { Last consultation }\end{array}$ & 1.31 & 1.25 & 0.29 & $\begin{array}{c}0.95-2.50 \\
(1.10-1.40)\end{array}$ \\
\hline
\end{tabular}


Ferri PM, Ferreira AR, Fagundes EDT, Liu SM, Roquete MLV, Penna FJ. Portal vein thrombosis in children and adolescents: 20 years experience of a pediatric hepatology reference center

Six patients $(10.9 \%)$ showed hypoalbuminemia at the first consultation, and in three of them the levels normalized during the follow-up, remaining low in three patients $(5.5 \%)$. Thrombocytopenia due to hypersplenism (platelets $<150.000 / \mathrm{mm}^{3}$ ) was detected in 28 patients $(50.9 \%)$ at the first consultation and six other patients developed thrombocytopenia along the follow-up, totaling 34 patients $(61.8 \%)$ at the last consultation. Prothrombin activity lower than $70 \%$ was observed in 19 patients $(34.5 \%)$ at the first consultation, and $11(57.9 \%)$ of them persisted with this alteration at the last consultation.

Ultrasound needed to be repeated in our service in 22 patients $(40 \%)$, because at the first exam of these patients the cavernomatous transformation of the portal vein was not identified.

\section{Episodes of upper gastrointestinal bleeding (UGIB)}

During the follow-up, 39 patients $(70.9 \%)$ had at least one episode of upper gastrointestinal bleeding. The number of bleedings of these patients showed a median of 2 (IR 1-3). Thirty-one patients $(79.5 \%$ of those who had bled) required at least one red blood cells transfusion during acute bleeding episode.

The age at which occurred the first bleeding showed a mean of $4.6 \pm 3.4$ years, median of 4 (QI 2-6) and $75 \%$ of these patients bled before 6 years old. Among the 39 patients who bled, 10 of them $(25.6 \%)$ showed recurrent bleeding during or after the secondary prophylaxis.

\section{Endoscopic approach and secondary prophylaxis of UGIB}

The esophageal varices profile observed at the first upper gastrointestinal endoscopy (UGIE) is described in Table 4.

Patients without the first UGIE had recently begun the follow-up and they did not carry out such exam yet. Given this, out of the 53 evaluated patients, $45(84.9 \%)$ showed description of esophageal varices at the first endoscopy. Others findings described in the endoscopic follow-up are showed in Table 5.

Thirty-two patients underwent secondary endoscopic prophylaxis. Fourteen patients $(43.8 \%)$ underwent treatment with sclerotherapy, 10 patients $(31.3 \%)$ with variceal band ligation and 8 patients $(25 \%)$ required association of both treatments.

In patients who underwent secondary prophylaxis, the number of sessions for eradication of the esophageal varices had a mean of $4.9 \pm 2.2$, median of 4 (IR 4-6), ranging from 2 to 11 sessions. Twelve out of the 32 patients $(37.5 \%)$ showed recurrence of esophageal varices during the endoscopic followup. The median number of bleedings was one episode, with an IR interval from 1 to 1.3 . Relapse occurred with median of 13.5 months after eradication (IR 12-36).

Esophageal stenosis due to endoscopic treatment occurred in five patients $(15.6 \%)$. Four out of these patients underwent sclerotherapy separately and in the last one this procedure was associated with EBL. This complication was treated with endoscopic dilatations.
TABLE 4. Esophageal varices observed at the first endoscopy

\begin{tabular}{lc}
\hline Varices classification & $\mathrm{n}(\%)$ \\
\hline Small caliber esophageal varices & $9(16.4 \%)$ \\
Medium caliber esophageal varices & $22(40 \%)$ \\
Large caliber esophageal varices & $14(25.5 \%)$ \\
No description of findings & $8(14.5 \%)$ \\
Patients without the first UGIE & $2(3.6 \%)$ \\
\hline
\end{tabular}

UGIE - Upper gastrointestinal endoscopy

TABLE 5. Endoscopic findings in the patients' follow-up

\begin{tabular}{lccc}
\hline Gastric varices & Gastropathy of portal hypertension \\
\hline GEV 1S* & 8 patients $(14.6 \%)$ & Mild & 41 patients $(74.6 \%)$ \\
GEV2S & 21 patients $(38.2 \%)$ & & 1 patient $(1.8 \%)$ \\
\hline IGV1S & 2 patients $(3.6 \%)$ & Severe & No patient \\
IGV2S & Notal & 42 patients $(76.4 \%)$ \\
\hline Total & 31 patients $(56.4 \%)$ & Total
\end{tabular}

"GEV1S : esophagogastric varices extending along the lesser curvature of the stomach

\# GEV2S: esophagogastric varices extending along the greater curvature towards the gastric fundus

\& IGV1S: isolated varices in the gastric fundus

$\S$ IGV2S: varices located in the gastric antrum, corpus or pylorus

\section{Surgical treatment}

Eight patients (14.5\%) underwent surgical intervention. Two underwent splenectomy in others services. Azygoportal disconnection due to UGIB of difficult control was performed in others two patients. Another patient required this procedure in the urgency due to persistent bleeding. Splenic artery ligation was performed in two patients and splenorenal shunt was performed in another due to hypersplenism. Only one patient died due to acute bleeding with no possibility of control.

\section{DISCUSSION}

Portal vein thrombosis is not frequent in the pediatric age group, however, it is an important cause of portal hypertension and shows as main morbidity the upper gastrointestinal bleeding ${ }^{(21,34,41,48)}$. As observed in the present study, PVT does not show gender predominance and its more common initial manifestations in children are upper gastrointestinal bleeding and splenomegaly, which corroborates results reported in the literature ${ }^{(1,6,41,47,50,53)}$. In the present casuistic, upper gastrointestinal bleeding was the main initial clinical manifestation in $52.7 \%$ of patients, followed by splenomegaly in $36.4 \%$. These data are similar to the ones reported by Gürakan et al. ${ }^{(20)}$ whose casuistic of 12 patient, showed the occurrence of UGIB in $50 \%$ of patients. On the other hand, Abd El-Hamid et al.(1) and Weiss et al. ${ }^{(53)}$ reported a greater proportion of patients with splenomegaly as the initial finding $(63 \%$ and $43.3 \%$, respectively). Thus, the possibility of PVT should be raised and a Doppler ultrasound exam should be requested in children and adolescents with UGIB or isolated finding of splenomegaly during the clinical exam. 
It should also be emphasized that a clinical situation of hypersplenism, manifested through thrombocytopenia associated with splenomegaly, is also frequently observed in pediatrics cases and, most of the time, the patients are referred firstly to the hematologist $\mathrm{t}^{(6,41,44,50)}$.

Today, the PVT etiology is considered multifactorial, with association of prothrombotic and local trigger factors found even in the pediatric age group ${ }^{(6,10,21,23,29,33,34,37,47,52,53)}$. The causes of PVT may be grouped into three categories: direct injury of the portal vein with subsequent thrombus formation; vascular malformation which includes stenosis or even atresia of the portal vein; and hypercoagulable conditions which favor the thrombus formation ${ }^{(6,15,19,22,39,49,50,52)}$. Cases that do not fit in these groups are denominated as idiopathic PVT and, due to the great percentage of these cases, recent studies, mainly in adults, have focused on the evaluation of new etiological factors ${ }^{(7,16,17,22,23)}$.

In the pediatric age group, the few available literature has been demonstrating that approximately $50 \%$ of the cases still remained with an unknown etiology $y^{(1,2,20,53)}$. This fact was also observed in the present study. Umbilical catheterization, omphalitis and neonatal sepsis are the most common causes in children ${ }^{(2,25,40,42)}$. The prevalence reported in two other studies was lower than the one observed in this study. Abd El-Hamid et al..$^{(1)}$ reported $12 \%$ of patients with umbilical catheterization and $7 \%$ with neonatal sepsis and Weiss et al. ${ }^{(53)}$ reported six patients $(20 \%)$ with catheterization history and two $(6.7 \%)$ with omphalitis among the 30 patients evaluated. On the other hand, Alvarez et al.$^{(2)}$ observed 44 patients among the 108 evaluated $(41 \%)$ with previous history of possible injury of the portal vein due to catheterization, omphalitis and surgery. This fact may be associated with the greater number of patients with prematurity history among the patients evaluated in the present study (32.7\% of patients). Data on prematurity was not reported in the other studies. No cases of omphalitis were observed in the present study.

Others possible causes are: abdominal trauma, surgical trauma, cysts and tumors in the portal hepatis, neonatal sepsis, congenital malformations and, more recently described, thrombophilias ${ }^{(6,9,17,20,21,30,41,50,52)}$. In spite of the lower prevalence, these factors are also reported in the pediatric age group. Abd El-Hamid et al. ${ }^{(1)}$ observed that in a sample of 108 patients with PVT, $8 \%$ had abdominal infection and $24 \%$ had congenital malformations. Alvarez et al. ${ }^{(2)}$ reported that $19 \%$ of the 108 patients had several congenital malformations. In the present study, such factors were also observed, indicating, thus, the importance of a rigorous evaluation of the patient. The association of factors observed in 10 patients $(18.2 \%)$ may be explained by the multifactorial nature of $\mathrm{PVT}^{(6,33,34,47,52)}$. Therefore, the approach of patients with possible diagnosis of PVT should be performed through a complete anamnesis, careful physical exam and laboratorial and radiological propedeutics. Anamnesis should mainly evaluate the presence of possible trigger factors, the patient's previous history, presence of others comorbidities and the family history.
Splenomegaly related to portal hypertension, even when not detected as the first manifestation, is present in most of patients ${ }^{(6,41)}$. In children, its presence occurred in $63 \%$ to $92 \%$ of the patients in the few casuistic reported in the literature ${ }^{(1,2,16,20,53)}$. The results of this study corroborate the others.

Laboratorial exams, in general, showed normal values of aminotransferases, albumin and coagulation tests. Albumin may be decreased and associated with ascites, for a short period, after episodes of $\mathrm{UGIB}^{(36,51)}$. On the other hand, patients with long-term portal hypertension secondary to PVT may show ascites without trigger factors ${ }^{(36)}$. This same group may also show reduced level of albumin, prolonged prothrombin time and increased levels of aminotransferases. The evaluation of adults, children and adolescents with prolonged evolution of the PVT showed that up to a fifth of these patients may develop such alterations ${ }^{(36)}$. The hepatic dysfunction may be attributed to the prolonged reduction of the portal blood flow and/or the development of portal biliopathy, which would indicate that PVT has a progressive character $^{(8,11,18,36)}$. No case of portal biliopathy, which has a progressive and silent manifestation, was observed in the present study. Attention should be given to the elevation of alkaline phosphatase and GGT. The portal biliopathy usually manifest mainly in the adulthood age ${ }^{(11,39)}$.

Hypoalbuminemia was observed in $10.9 \%$ of patients at the diagnosis and, during the clinical follow-up, 5.5\% maintained this alteration. This fact may be occurred due to the presence of UGIB episodes, but it may be also due to the possible hepatic dysfunction associated with PVT. The reduction of prothrombin activity was observed in $34.5 \%$ of patients, which was also reported in the literature, and it has been attributed to increased consumption of coagulation factors due to the portal obstruction and the formation of portosystemic shunts and to the reduced hepatic blood flow ${ }^{(18,23,26)}$.

Hypersplenism leading to thrombocytopenia was detected in $61.8 \%$ of patients, and, in spite of the reduction in the number of platelets, they are functionally normal ${ }^{(4)}$. Two patients had severe thrombocytopenia associated with esophageal varices, which led to surgical intervention. The procedure used was ligation of the splenic artery, with good results. Two other patients, evaluated in other services, underwent splenectomy, however the diagnosis of PVT was given after. Therefore, it is important to include the PVT in the differential diagnosis of afebrile splenomegaly so that an appropriate therapeutic approach may be accomplished in these cases, since splenectomy is not indicated in the cases of portal hypertension secondary to PVT.

For the PVT diagnosis, the ultrasound exam, performed out of the Hospital das Clínicas' service, needed to be repeated in $40 \%$ of patients. The first examination of these patients had not shown cavernomatous transformation. Doppler ultrasound is considered effective, less invasive and less expensive, so, it is the method of first choice for investigation $^{(6,20,25,41,50,52)}$. Its sensitivity and specificity are, however, examiner-dependent. Therefore, PVT may not be 
diagnosed correctly by an inexperienced examiner, which may lead to an inadequate approach to the patient, and, also, to a delay in the control of complications. The presence of neovascularization in the thrombus area (cavernoma) occurs in the chronic cases $(6,20,41,50,52)$

Abd El-Hamid et al. ${ }^{(1)}$, Weiss et al. ${ }^{(53)}$ and Alvarez et al. ${ }^{(2)}$ reported percentage of UGIB similar to the one observed in the present study. Such percentage ranged from $69 \%$ to $79 \%$ in those studies. The mean and median of age in the present sample at the first episode were 4.6 and 4 , respectively, (IR 2-6) very close to the ones reported by Abd El-Hamid et al..$^{(1)}$ (mean $=4.6$ year old). In the study of Zargar et al. ${ }^{(56)}$ the mean age was 6.4 years. When the endoscopic and/or drug secondary prophylaxis are not established, or it is unsuccessful, the chance of new bleeding is higher ${ }^{(10,28,56)}$. In the present study, the mean number of UGIB episodes was the same as the one reported by Abd El-Hamid et al. ${ }^{(1)}$.

The UGIB treatment is based on the initial hemodynamic stabilization of the patient, cardiopulmonary resuscitation when necessary and evaluation of the need for a red blood cells transfusion, which was required in $79.5 \%$ of patients at least once ${ }^{(41)}$. Abd El-Hamid et al. ${ }^{(1)}$ reported the need for blood transfusion in 49 patients $(45.4 \%)$.

Even patients who did not bleed had esophageal varices at the first endoscopic exam. So, it is important to monitor all patients with PVT with gastrointestinal endoscopy to assess the presence of varices and to program the best approach of the endoscopic prophylaxis when it is necessary ${ }^{(45)}$.

The prevention of recurrence of UGIB secondary to bleeding from esophageal varices is fundamental for the follow-up of patients with portal hypertension. The adults' treatment includes the use of drugs such as propranolol, endoscopic measures (sclerotherapy or EBL) and portosystemic shunts ${ }^{(10,13,56)}$. As there are few studies in pediatrics, the treatment for this age group has been based on extrapolations of treatment in adults and in experience reported in the few pediatric casuistics found in the literature $(10,27,28,46,56)$.

Thirty-two patients $(58.2 \%)$ underwent secondary endoscopic prophylaxis in our service. EBL has become the choice procedure, because studies have shown that this is a safe (lower incidence of complications) and effective procedure (shorter interval time to varices eradication, lower number of sessions and lower rebleeding ratio) for the secondary prophylaxis in children ${ }^{(10,28,46,56)}$. However, sclerotherapy still has room in the treatment of younger children, mainly in those who it is not possible the accomplishment of EBL due to technical limitations. Maksoud-Filho et al. ${ }^{(27)}$, in recent study, showed that sclerotherapy is effective and safe for the treatment of varices in children.

Among the major complications of endoscopic treatment, esophageal stenosis is the most common. It occurs most often associated with sclerotherapy, but it may also result from EBL ${ }^{(10,28,56)}$. Abd El-Hamid et al..$^{(1)}$ reported complications in $34 \%$ of the 108 patients and stenosis and ulcers were the most commonly complications. The difference of prevalences observed between the study of Abd El-Hamid et al. ${ }^{(1)}$ and the present study may be related to the most frequent use of sclerotherapy in that other casuistic.

Surgical treatment is indicated in cases of recurrent bleeding even after appropriate endoscopic treatment, in massive splenomegaly and/or severe hypersplenism, in the retardation of children growth and in the symptomatic portal biliopathy ${ }^{(3,14,41,52)}$. The appearance of new surgical techniques has been improving the results obtained with shunts in children ${ }^{(3,14,24,26)}$. Today, there still preference to the distal splenorenal shunt in most services, but the Rex shunt (mesenteric left bypass) has emerged as the most appropriate technique and the one of choice $^{(3,13,23)}$. Our service has no experience with this technique, so this was not performed in any patient.

Only one patient $(1.8 \%)$ died due to acute bleeding episode. Mortality due to variceal bleeding in patients with PVT, but without cirrhosis, is of approximately $2 \%$ to $5 \%$ in adults. In children, the prognostic is usually better due to the low incidence of associated diseases, with a survival rate in 10 years higher than $70 \%{ }^{(51)}$.

The patients assisted at the Hospital das Clínicas of UFMG showed characteristics similar to those evaluated in other pediatric samples and they had access to an appropriate clinical and endoscopic prophylactic treatment. However, there still is a lack of experience with the accomplishment of shunts, mainly the Rex shunt, which has become a treatment option in the PVT cases. As it is a non frequent condition and its diagnosis depends on the knowledge of the disease, it is possible that the number of cases referred to the reference service is lower than the one actually observed in the population.

PVT is one of the most important causes of UGIB in children and the etiological factors are absent in up to $50 \%$ of patients. In every child with afebrile splenomegaly and/or hematemesis, without hepatomegaly and with normal hepatic function tests, we should suspect of PVT. Thus, an appropriate diagnosis and therapy is desirable in an attempt to reduce morbidity and mortality and improve quality of life of these patients. 
Ferri PM, Ferreira AR, Fagundes EDT, Liu SM, Roquete MLV, Penna FJ. Trombose de veia porta em crianças e adolescentes: experiência de 20 anos de um serviço de referência em hepatologia pediátrica. Arq Gastroenterol. 2012;49(1):69-76.

RESUMO - Contexto - Trombose da veia porta refere-se a uma obstrução total ou parcial do fluxo de sangue nesta veia devido à formação de um trombo. É uma causa importante da hipertensão porta na faixa etária pediátrica, com taxas elevadas de morbidade devido a sua principal complicação - a hemorragia digestiva alta. Objetivo - Descrever o grupo de crianças e adolescentes com trombose de veia porta sem doença hepática associada do Ambulatório de Hepatologia Pediátrica do Hospital das Clínicas da UFMG, Belo Horizonte, MG, Brasil, com ênfase no diagnóstico, forma de apresentação, complicações clínicas e na abordagem da hipertensão porta. Métodos - Trata-se de estudo descritivo de uma série de casos de crianças e adolescentes atendidos de janeiro de 1990 a dezembro de 2010. O diagnóstico de trombose de veia porta foi estabelecido por ultrassonografia. Resultados - Dos 55 pacientes analisados, 30 (54,5\%) eram do gênero masculino. Em 29 pacientes (52,7\%) não foi identificado nenhum fator de risco para trombose de veia porta. A forma de apresentação predominante foi hemorragia digestiva alta (52,7\%). Em 20 pacientes (36,4\%), a manifestação inicial foi esplenomegalia. Durante todo o período de seguimento, 39 pacientes $(70,9 \%)$ apresentaram, pelo menos, um episódio de hemorragia digestiva alta. A média de idade dos pacientes neste primeiro episódio foi de 4,6 $\pm 3,4$ anos. O exame endoscópico, seja realizado na urgência ou eletivamente para pesquisa de varizes esofágicas, mostrou sua presença em $84,9 \%$ dos pacientes avaliados. O tratamento endoscópico profilático foi realizado com ligadura elástica de varizes em 31,3\% dos pacientes. Apenas um evoluiu para óbito devido a sangramento refratário. Conclusões - A trombose de veia porta é uma das causas mais importantes de hemorragia digestiva alta em crianças. Deve-se suspeitar de trombose de veia porta em toda criança com esplenomegalia afebril e/ou hematêmese, sem hepatomegalia e com testes de função hepática normais. Desta forma, uma abordagem diagnóstica e terapêutica adequada é desejável na tentativa de reduzir a morbimortalidade.

DESCRITORES - Trombose venosa. Veia porta. Hipertensão portal. Crianças. Adolescentes.

\section{REFERENCES}

1. Abd El-Hamid N, Taylor RM, Marinello D, Mufti GJ, Patel R, Mieli-Vergani G, Davenport M, Dhawan A. Aetiology and management of extrahepatic portal vein obstruction in children: King's College Hospital experience. J Pediatr Gastroenterol Nutr. 2008;47:630-4.

2. Alvarez F, Bernard O, Brunelle F, Hadchouel P, Odièvre M, Alagille D. Portal obstruction in children. I. Clinical investigation and hemorrhage risk. J Pediatr. 1983;103:696-702.

3. Ates O, Hakgüder G, Olguner M, Akgür FM. Extrahepatic portal hypertension treated by anastomosing inferior mesenteric vein to left portal vein at Rex recessus. J Pediatr Surg. 2003;38:E10-11.

4. Bajaj JS, Bhattacharjee J, Sarin SK. Coagulation profile and platelet function in patients with extrahepatic portal vein obstruction and non-cirrhotic portal fibrosis. J Gastroenterol Hepatol. 2001;16:641-6.

5. Balfour GW, Stewart G. Case of enlarge spleen complicated with ascites, both depending upon varicose dilatation and thrombosis of the portal vein. Edinburgh Med J. 1869;14:589-99.

6. Bayraktar Y, Harmanci O. Etiology and consequences of thrombosis in abdomina vessels. World J Gastroenterol. 2006;12:1165-74.

7. Bhattacharyya M, Makharia G, Kannan M, Ahmed RP, Gupta PK, Saxena R. Inherited prothrombotic defects in Budd-Chiari syndrome and portal vein thrombosis: a study from North India. Am J Clin Pathol. 2004;121:844-7.

8. Bilodeau M, Aubry MC, Houle R, Burnes PN, Ethier C. Evaluation of hepatocyte injury following partial ligation of the left portal vein. J Hepatol. 1999;30:29-37.

9. Bittencourt PL, Couto CA, Ribeiro DD. Portal vein thrombosis and budd-Chiari syndrome. Clin Liver Dis. 2009;13:127-44.

10. Celinska-Cedro D, Teisseyre M, Woynarowski M, Socha P, Socha J, Ryzko J. Endoscopic ligation of esophageal varices for prophylaxis of first bleeding in children and adolescents with portal hypertension: preliminary results of a prospective study. J Pediatr Surg. 2003;38:1008-11.

11. Chandra R, Kapoor D, Tharakan A, Chaudhary A, Sarin SK. Portal biliopathy. J Gastroenterol Hepatol. 2001;16:1086-92.

12. Condat B, Valla D. Nonmalignant portal vein thrombosis in adults. Nat Clin Pract Gastroenterol Hepatol. 2006;3:505-15.

13. de Franchis R. Evolving consensus in portal hypertension. Report of the Baveno IV consensus workshop on methodology of diagnosis and therapy in portal hypertension. J Hepatol. 2005;43:167-76.

14. de Ville de Goyet J, Alberti D, Falchetti D, Rigamonti W, Matricardi L, Clapuyt P, Sokal EM, Otte JB, Caccia G. Treatment of extrahepatic portal hypertension in children by mesenteric-to-left portal vein bypass: a new physiological procedure. Eur J Surg. 1999;165:777-81.

15. Denninger MH, Chait Y, Casadevall N, Hillaire S, Guillin MC, Bezeaud A, Erlinger S, Briere J, Valla D. Cause of portal or hepatic venous thrombosis in adults: the role of multiple concurrent factors. Hepatology. 2000;31:587-91.
16. Dentali F, Squizzato A, Brivio L, Appio L, Campiotti L, Crowther M, Grandi AM, Ageno W. JAK2V617F mutation for the early diagnosis of $\mathrm{Ph}$ - myeloproliferative neoplasms in patients with venous thromboembolism: a meta-analysis. Blood;2009;113:5617-23

17. El-Karaksy H, El-Koofy N, El-Hawary M, Mostafa A, Aziz M, El-Shabrawi M, Mohsen NA, Kotb M, El-Raziky M,El-Sonoon MA, A-Kader H. Prevalence of factor V Leiden mutation and other hereditary thrombophilic factors in Egyptian children with portal vein thrombosis: results of a single-center case-control study Ann Hematol. 2004;83:712-5.

18. Fisher NC, Wilde JT, Roper J, Elias E. Deficiency of natural anticoagulant proteins $\mathrm{C}, \mathrm{S}$, and antithrombin in portal vein thrombosis: a secondary phenomenon? Gut 2000;46:534-9.

19. Guimarães H, Castelo L, Guimarães J, Cardoso A, d'Orey C, Mateus M, Almeida A, Amil Dias J, Ramos I, Teixeira Santos N. Does umbilical vein catheterization to exchange transfusion lead to portal vein thrombosis? Eur J Pediatr. 1998;157:461-3.

20. Gürakan F, Eren M, Koçak N, Yüce A, Ozen H, Temizel IN, Demir H. Extrahepatic portal vein thrombosis in children: etiology and long-term follow-up. J Clin Gastroenterol. 2004;38:368-72.

21. Heller C, Schobess R, Kurnik K, Junker R, Günther G, Kreuz W, Nowak-Götti U. Abdominal venous thrombosis in neonates and infants: role of prothrombotic risk factors - a multicentre case-control study. For the Childhood Thrombophilia Study Group. Br J Haematol. 2000;111:534-9.

22. Hirohata Y, Murata A, Abe S, Otsuki M. Portal vein thrombosis associated with antiphospholipid syndrome. J Gastroenterol. 2001;36:574-8.

23. Janssen HL, Meinardi JR, Vleggaar FP, van Uum SH, Haagsma EB, van Der Meer FJ, van Hattum J, Chamuleau RA, Adang RP, Vandenbrouke JP, van Hoek B, Rosendaal FR. Factor V Leiden mutation, prothrombin gene mutation, and deficiencies in coagulation inhibitors associated with Budd-Chiari syndrome and portal vein thrombosis: results of a case-control study. Blood. 2000;96:2364-8.

24. Kato T, Romero R, Koutouby R, Mittal NK, Thompson JF, Schleien CL, Tzakis AG. Portosystemic shunting in children during the era of endoscopic therapy: improved postoperative growth parameters. J Pediatr Gastroenterol Nutr. 2000;30:419-25.

25. Kim JH, Lee YS, Kim SH, Lee SK, Lim MK, Kim HS. Does umbilical vein catheterization lead to portal venous thrombosis? Prospective US evaluation in 100 neonates. Radiology. 2001;219:645-50.

26. Mack CL, Superina RA, Whitington PF. Surgical restoration of portal flow corrects procoagulant and anticoagulant deficiencies associated with extrahepatic portal vein thrombosis. J Pediatr. 2003;142:197-9.

27. Maksoud-Filho JG, Gonçalves ME, Cardoso SR, Gibelli NE, Tannuri U. Long term follow-up of children with extrahepatic portal vein obstruction: impact of an endoscopic sclerotherapy program on bleeding episodes, hepatic function, hypersplenism, and mortality. J Pediatr Surg. 2009;44:1877-83.

28. McKiernan PJ, Beath SV, Davison SM. A prospective study of endoscopic esophageal variceal ligation using a multiband ligator. J Pediatr Gastroentero Nutr. 2002;34:207-11. 
29. Northup PG, Sundaram V, Fallon MB, Reddy KR, Balogun RA, Sanyal AJ, Anstee QM, Hoffman MR, Ikura I, Caldwell SH. Hypercoagulation and thrombophilia in liver disease. J Thromb Haemost. 2008;6:2-9.

30. Odièvre M, Pigé G, Alagille D. Congenital abnormalities associated with extrahepatic portal hypertension. Arch Dis Child. 1977;52:383-5.

31. Ogren M, Bergqvist D, Björck M, Acosta S, Eriksson H, Sternby NH. Portal vein thrombosis: prevalence, patient characteristics and lifetime risk: a population study based on 23,796 consecutive autopsies. World J Gastroenterol. 2006;12:2115-9.

32. Pinto RB, Silveira TR, Bandinelli E, Röhsig L. Portal vein thrombosis in children and adolescents: the low prevalence of hereditary thrombophilic disorders. J Pediatr Surg. 2004;39:1356-61.

33. Ponziani FR, Zocco MA, Campanale C, Rinninella E, Tortora A, Di Maurizio L, Bombardieri G, De Cristofaro R, De Gaetano AM, Landolfi R, Gasbarrini A. Portal vein thrombosis: insight into physiopathology, diagnosis, and treatment. World J Gastroenterol. 2010;16:143-55.

34. Primignani M. Portal vein thrombosis, revisited. Dig Liver Dis. 2010;42:163-70.

35. Pugliese RP, D'Amico EA, Rocha TR, Bydlowski SP, Venturinelli ML, Cardoso RA, Miura IK, Chamone DA, Porta G. Risk factors in children and adolescents with portal vein thrombosis (PVT) and portal hypertension. Hepatology. 1998;28:551A

36. Rangari M, Gupta R, Jain M, Malhotra V, Sarin SK. Hepatic dysfunction in patients with extrahepatic portal venous obstruction. Liver Int. 2003;23:434-9.

37. Rosendaal FR. Venous thrombosis: a multicausal disease. Lancet. 1999;353:1167-73.

38. Sakha SH, Rafeey M, Tarzamani MK. Portal venous thrombosis after umbilical vein catheterization. Indian J Gastroenterol. 2007;26:283-4.

39. Sarin SK, Agarwal SR. Extrahepatic portal vein obstruction. Semin Liver Dis. 2002;22:43-58.

40. Sarin SK, Sollano JD, Chawla YK, Amarapurkar D, Hamid S, Hashizume M, Jafri W, Kumar A, Kudo M, Lesmana LA, Sharma BC, Shiha G, Janaka de Silva H. Consensus on extra-hepatic portal vein obstruction. Liver Int. 2006;26:512-9.

41. Schettino GC, Fagundes ED, Roquete ML, Ferreira AR, Penna FJ. Portal vein thrombosis in children and adolescents. J Pediatr (Rio J). 2006;82:171-8.

42. Schwartz DS, Gettner PA, Konstantino MM, Bartley CL, Keller MS, Ehrenkranz RA, Jacobs HC. Umbilical venous catheterization and the risk of portal vein thrombosis. J Pediatr. 1997;131:760-2.

43. Seixas CA, Hessel G, Siqueira LH, Machado TF, Gallizoni AM, AnnichinoBizzacchi JM. Study of hemostasis in pediatric patients with portal vein thrombosis. Haematologica. 1998;83:955-6.
44. Senders Aguirre B, Garcia Sanz MC, Casa Morcillo A. Trombosis de la vena porta. Ana Esp Pediatr. 2001;55:565-8.

45. Sharma S, Kumar SI, Poddar U, Yachha SK, Aggarwal R. Factor V Leiden and prothrombin gene G20210A mutations are uncommon in portal vein thrombosis in India. Indian J Gastroenterol. 2006;25:236-9.

46. Shneider B, Emre S, Groszmann R, Karani J, McKiernan P, Sarin S, Shashidhar H, Squires R, Superina R, de Ville de Goyet J, de Franchis R. Expert pediatric opinion on the Report of the Baveno IV consensus workshop on methodology of diagnosis and therapy in portal hypertension. Pediatr Transplant. 2006;10:893-907.

47. Sogaard KK, Astrup LB, Vilstrup H, Gronbaek H. Portal vein thrombosis; risk factors, clinical presentation and treatment. BMC Gastroenterol. 2007;7:34

48. Uttenreuther-Fischer MM, Vetter B, Hellmann C, Otting U, Ziemer S, Hausdorf G, Gaedicke G, Kulozik AE. Paediatric thrombo-embolism: the influence of non-genetic factors and the role of activated protein $\mathrm{C}$ resistance and protein $\mathrm{C}$ deficiency. Eur J Pediatr. 1997;156:277-81.

49. Valla DC, Condat B. Portal vein thrombosis in adults: pathophysiology, pathogenesis and management. J Hepatol. 2000;32:865-71.

50. Wang JT, Zhao HY, Liu YL. Portal vein thrombosis. Hepatobiliary Pancreat Dis Int. 2005;4:515-8.

51. Webb LJ, Sherlock S. The aetiology, presentation and natural history of extrahepatic portal venous obstruction. Q J Med. 1979:48:627-39.

52. Webster GJ, Burroughs AK, Riordan SM. Review article: portal vein thrombosis -- new insights into aetiology and management. Aliment Pharmacol Ther. 2005;21:1-9.

53. Weiss B, Shteyer E, Vivante A, Berkowitz D, Reif S, Weizman Z, Bujanover Y, Shapiro R. Etiology and long-term outcome of extrahepatic portal vein obstruction in children. World J Gastroenterol. $2010 ; 16: 4968-72$.

54. Yachha SK, Aggarwal R, Sharma BC, Misra RN, Aggarwal A, Naik SR. Functional protein $\mathrm{C}$ and anti-cardiolipin antibody in children with portal vein thrombosis. Indian J Gastroenterol. 2001;20:47-9.

55. Yamada RM, Antunes MM, Cardoso SR, Servidoni MF, Hessel G. [Porta vein thrombosis in children: clinical and laboratory study of 26 cases]. Arq Gastroenterol. 1999;36:49-53.

56. Zargar SA, Javid G, Khan BA, Yattoo GN, Shah AH, Gulzar GM, Singh J, Rehman BU, Din Z. Endoscopic ligation compared with sclerotherapy for bleeding esophageal varices in children with extrahepatic portal venous obstruction. Hepatology. 2002;36:666-72. 